\title{
Peran Kepala Sekolah dalam Menerapkan Disiplin Kerja Guru
}

\author{
Arjunaita, Happy Fitria, Rohana \\ ${ }^{1}$ Kementerian Agama Banyuasin, ${ }^{2,3}$ Universitas PGRI Palembang \\ e-mail: ${ }^{1}$ arjuanita97@gmail.com, ${ }^{2}$ happyfitriamufly@univpgri-palembang.ac.id, \\ 3rohana@univpgri-palembang.ac.id
}

\begin{abstract}
Abstrak
Penelitian ini bertujuan untuk mendeskripsikperan kepala sekolah dalam menerapkan disiplin kerja guru yang bertugas di MAN 1 Banyuasin Kecamatan Banyuasin III Kabupaten Banyuasin, mendeskripsikan disiplin kerja guru yang bertugas di MAN 1 Banyuasin Kecamatan Banyuasin III Kabupaten Banyuasin Penelitian ini menggunakan metode deskriptif dengan pendekatan kualitatif. Teknik pengumpulan data dilakukan dengan menggunakan wawancara, observasi dan studi dokumentasi. Data hasil penelitian dianalisis dengan dengan mereduksi data, mendisplay data dan memperivikasi data. Hasil penelitian ini menunjukkan bahwa peran kepala MAN 1 Banyuasin Kecamatan Banyuasin III kabupaten Banyuasin dalam menerapkan disiplin kerja bagi guru MAN 1 Banyuasin kecamatan Banyuasin III kabupaten Banyuasin cukup baik dan disiplin kerja guru MAN 1 Banyuasin Kecamatan Banyuasin III Kabupaten Banyuasin sudah baik. Sedangkan hambatan yang dialami kepala MAN 1 Banyuasin Kecamatan Banyuasin III Kabupaten Banyuasin dalam menerapkan displin kerja adalah keadaan fisik biologis yang kurang sehat, kondisi tempat tinggal, faktor geografis
\end{abstract}

Kata Kunci: Peran Kepala Sekolah, Disiplin Kerja Guru, Kualitas Pendidikan

\section{Abstract}

This study aims to describe the role of the principal in implementing the discipline of the work of teachers who serve in MAN 1 Banyuasin, Banyuasin III District, Banyuasin Regency, to describe the discipline of the work of teachers who serve in MAN 1 Banyuasin, Banyuasin III District, Banyuasin Regency. This research uses descriptive methods with a qualitative approach. The data collection technique is done by using interviews, observation and documentation study. The research data were analyzed by reducing the data, displaying the data and verifying the data. The results of this study indicate that the role of the head of MAN 1 Banyuasin, Banyuasin III District, Banyuasin Regency in implementing work discipline for MAN 1 Banyuasin teachers, Banyuasin III district, Banyuasin district is quite good and the work discipline of MAN 1 Banyuasin teachers in Banyuasin III District Banyuasin Regency is good. While the obstacles experienced by the head of MAN 1 Banyuasin, Banyuasin III District, Banyuasin Regency in implementing work discipline are the physical, biological conditions that are less healthy, the conditions of residence, geographical factors.

Keywords: Role of Principal, Teacher Work Discipline, Quality of Education

\section{PENDAHULUAN}

Kepala sekolah merupakan salah satu komponen yang paling berperan dalam meningkatkan kualitas pendidikan, yang memiliki tanggung jawab untuk memajukan pendidikan yang ia pimpin. Seperti diungkapkan Mulyasa (2003) bahwa erat hubungannya antara mutu kepala sekolah dengan berbagai kehidupan sekolah seperti disiplin sekolah, iklim budaya sekolah, dan menurunnya prilaku nakal guru dan peserta didik

Sekolah yang disiplin akan melahirkan kondisi yang baik, nyaman, tentram dan teratur. Istilah disiplin merupakan saduran dari Bahasa Inggris yaitu "discipline" yang berarti pelatihan pola pikir dan karakter dan upaya pengembangan dan pengendalian pola pikir dan 
karakter yang dimaksudkan untuk menciptakan kepatuhan dan ketaatan kepada perilaku yang tertib dan tertatur. Mulyasa (2003:25) mengatakan bahwa disiplin pada dasarnya taat aturan pada ketentuan yang berlaku. Disiplin merupakan kepatuhan untuk menghormati dan dilaksanakan suatu sistem yang mengharuskan orang untuk tunduk kepada keputusan perintah atau peraturan yang berlaku. Kemudian disiplin adalah kesadaran dan kesediaan seseorang menaati semua peraturan dan norma-norma yang berlaku. Dengan demikian dapat disimpulkan disiplin itu merupakan kesediaan atau ketaatan seseorang untuk mematuhi aturan, tata tertib, norma yang telah dibuat oleh pimpinan yang dilandasi oleh kesadaran dan kesediaan dalam diri setiap guru (Utama dkk, 2020; Wandasari dkk, 2019). Dalam melaksanakan tugas sebagai tenaga pendidik, disiplin berperan dalam mempengaruhi, mendorong, mengendalikan, mengubah, membina dan mengubah perilakuperilaku yang tidak baik dan mencapai tujuan sesuai dengan nilai-nilai yang diinginkan dan diteladani.

Guru merupakan salah satu komponen penting dalam proses pendidikan yang ikut berperan dalam pembentukan sumber daya manusia (SDM). Peran guru dalam pendidikan tidak hanya sebatas dalam pembelajaran, tetapi sebagai informator, organisator, motivator, fasilitator, mediator, inisiator, dan evaluator. Untuk mencapai tujuan pendidikan sangat dibutuhkan guru yang mempunyai potensi, rasa pengabdian yang tinggi dan bertanggung jawab dalam melaksanakan tugas profesinya. Usman (2007) menyatakan bahwa, tugas guru sebagai profesi meliputi, mendidik, mengajar, dan melatih. Mendidik berarti meneruskan dan mengembangkan nilai-nilai hidup. Mengajar berarti meneruskan dan mengembangkan ilmu pengetahuan dan teknologi. Sedangkan melatih berarti mengembangkan keterampilan-keterampilan pada siswa, termasuk melatih siswa dalam mematuhi disiplin yang diterapkan disekolah

Mencermati uraian di atas, terlihat besarnya peran guru dalam membantu pertumbuhan dan perkembangan peserta didik. Guru memiliki peran dan fungsi yang sangat penting dalam membentuk kepribadian, akhlak, mentalitas, dan moral anak. Dengan demikian dapat dikatakan tercapainya tujuan pendidikan di sekolah sangat dipengaruhi oleh sikap guru dalam melaksanakan tugas profesinya. Kenyataan inilah yang mengharuskan guru memiliki disiplin yang tinggi dalam melaksanakan tugas dan fungsinya, karena guru adalah tokoh yang menjadi panutan bagi peserta didik dan lingkungannnya. Tu'u (2004) berpendapat tentang disiplin sebagai ketaatan terhadap peraturan dan norma kehidupan masyarakat berbangsa dan bernegara yang berlaku, yang dilaksanakan secara sadar dan ikhlas, lahir bathin. sehingga timbul rasa malu apabila terkena sangsi dan rasa takut terhadap Tuhan Yang Maha Esa. Perilaku tersebut diikuti berdasarkan dan keyakinan bahwa hal itulah yang benar, dan keinsyafan bahwa hal itu bermanfaat bagi dirinya dan masyarakat. Pada sisi lain, disiplin adalah alat untuk menciptakan perilaku dan tata tertib manusia sebagai kelompok masyarakat. Oleh sebab itu, disiplin berarti hukuman atau sangsi yang berbobot mengatur dan mengendalikan perilaku.

Disiplin adalah kesadaran dan kesediaan seseorang menaati semua peraturan perusahaan dan norma-norma sosial yang berlaku. Adapun arti kesadaran adalah sikap seseorang yang secara sukarela menaati semua peraturan dan sadar akan tugas dan tanggung jawabnya. Sedangkan arti kesediaan menurut Hasibuan (2009) adalah suatu sikap, tingkah laku, dan perbuatan seseorang yang sesuai dengan peraturan perusahaan baik yang tertulis maupun tidak. Menurut Mangkunegara (2002) disiplin kerja dapat diartikan sebagai pelaksanaan manajemen untuk memperteguh pedoman-pedoman organisasi.

Disiplin pada hakikatnya adalah kemampuan untuk mengendalikan diri dalam bentuk tidak melakukan sesuatu tindakan yang tidak sesuai dan bertentangan dengan sesuatu yang telah ditetapkan dan melakukan sesuatu yang mendukung dan melindungi sesuatu yang telah ditetapkan. Dalam kehidupan sehari-hari dikenal dengan disiplin diri, disiplin belajar dan disiplin kerja. Disiplin kerja merupakan kemampuan seseorang untuk secara teratur, tekun secara terus-menerus dan bekerja sesuai dengan aturan-aturan yang berlaku dengan tidak melanggar aturan-aturan yang sudah ditetapkan. 
Hasibuan (2009) mengatakan bahwa pada dasarnya banyak indikator yang mempengaruhi tingkat kedisplinan guru dalam melaksanakan tugasnya disekolah di antaranya ialah (1) tujuan dan kemampuan, (2) teladan pimpinan, (3) balas jasa (gaji dan kesejahteraan), (4) keadilan, (5) waskat (pengawasan melekat), (6) sanksi hukuman, (7) ketegasan, dan (8) hubungan kemanusiaan. Oleh karena itu disiplin merupakan salah satu fungsi manajemen sumber daya manusia yang penting dan merupakan kunci terwujudnya tujuan, karena tanpa adanya disiplin maka sulit mewujudkan tujuan yang maksimal (Sedarmayanti, 2007).

Melalui disiplin pula timbul keinginan dan kesadaran untuk menaati peraturan organisasi dan norma sosial. Namun tetap pengawasan terhadap pelaksanaan disiplin tersebut perlu dilakukan. Disiplin kerja adalah persepsi guru terhadap sikap pribadi guru dalam hal ketertiban dan keteraturan diri yang dimiliki oleh guru dalam bekerja di sekolah tanpa ada pelanggaran-pelanggaran yang merugikan dirinya, orang lain, atau lingkungannya.

Menurut Tu'u (2004) citra guru terbentuk pada profesi yang melekat pada pribadi guru itu, bagaimana sikap keprofesionalannya dalam melaksanakan tugas dan kewajibannya. Citra guru akan dinilai baik oleh masyarakat apabila dapat menunjukkan kepada masyarakat bahwa ia layak menjadi panutan atau teladan masyarakat sekelilingnya. Masyarakat terutama akan melihat bagaimana sikap dan perbuatan guru itu sehari-hari, apakah memang ada yang patut diteladani atau tidak.

Salah satu faktor utama yang sangat berpengaruh dalam keberhasilan pembelajaran adalah keberadaan guru (Khasanah dkk, 2019; Apriana dkk, 2019; Andriani dkk, 2018). Mengingat keberadaan guru dalam proses kegiatan belajar mengajar sangat berpengaruh, maka sudah semestinya kualitas guru harus diperhatikan. Sebagaimana telah dikemukakan di atas, bahwa dalam upaya meningkatkan mutu pendidikan, aspek utama yang ditentukan adalah kualitas guru. Untuk itu, upaya awal yang dilakukan dalam peningkatan mutu pendidikan adalah kualitas guru yang berbentuk disiplin kerja

Purwanto (2006) mengatakan bahwa untuk menjamin terpeliharanya tata tertib dan kelancaran pelaksanaan tugas dalam mencapai tujuan sekolah, maka diperlukan guru yang penuh kesetiaan dan ketaatan pada peraturan yang berlaku dan sadar akan tanggung jawabnya untuk menyelenggarakan tujuan sekolah. Dengan kata lain kedisiplinan para guru sangat diperlukan dalam meningkatkan tujuan sekolah. Untuk itu, menerapkan disiplin merupakan hal yang sangat penting, sebab dengan kedisiplinan dapat diketahui seberapa besar peraturan-peraturan dapat ditaati oleh guru. Dengan kedisiplinan di dalam mengajar guru proses pembelajaran akan terlaksana secara efektif dan efisien. Keberhasilan belajar siswa itu tidak terlepas dari keberhasilan proses belajar mengajar yang kemungkinan besar di pengaruhi oleh kedisiplinan guru.

Dalam menerapkan dan meningkatkan disiplin kerja guru di MAN 1 Banyuasin, tentunya mengalami beberapa kendala. Berdasarkan hasil observasi dan wawancara peneliti, terdapat beberapa penemuan; pertama, kurangnya disiplin dalam frekuensi kehadiran guru yang bertugas di MAN 1 Banyuasin.

Berdasarkan data yang peneliti peroleh dari bagian tata usaha MAN 1 Banyuasin mengenai rekapitulasi kehadiran guru MAN 1 Banyuasin selama tahun 2018-2019 mengalami presentasi kenaikan dan penurunan. Adapun persentase kehadiran guru sebagai berikut periode tahun 2018, frekuensi kehadiran guru sebesar 90\%; tahun 2019 mengalami penurunan menjadi sebesar 70\%. Meskipun untuk kehadiran sudah dilaksanakan dan diberlakukan sistem finger print (sidik jari). Tentunya upaya kepala sekolah sangat membantu dalam menerapkan, menegakkan dan meningkatkan frekuensi kehadiran guru. Namun ada saja kendala dari penggunaan finger print, yaitu ada beberapa guru yang datang ke sekolah hanya untuk absensi kehadiran dengan menggunakan finger print, setelah itu guru pulang atau melakukan kegiatan lain di luar sekolah.

Robins (2005) mengatakan bahwa ada 3 (tiga) aspek disiplin kerja, diantaranya, sebagai berikut 1) Disiplin waktu, ini diartikan sebagai sikap atau tingkah laku yang menunjukkan ketaatan terhadap jam kerja yang meliputi kehadiran dan kepatuhan pegawai 
pada jam kerja, pegawai melaksanakan tugas dengan tepat waktu dan benar. 2) Disiplin peraturan. Peraturan dan juga tata tertib yang tertulis dan tidak tertulis dibuat agar tujuan suatu organisasi bisa dicapai dengan baik. Untuk itu dibutuhkan sikap setia dari pegawai terhadap komitmen yang telah ditetapkan tersebut. Kesetiaan yang dimaksudkan yaitu taat dan patuh dalam melaksanakan perintah dari atasan dan peraturan, tata tertib yang telah ditetapkan serta ketaatan pegawai dalam menggunakan kelengkapan pakaian seragam yang telah ditentukan organisasi atau perusahaan. 3) Disiplin tanggung jawab. Salah satu wujud tanggung jawab pegawai yaitu penggunaan dan pemeliharaan peralatan yang sebaikbaiknya sehingga dapat menunjang kegiatan kantor berjalan dengan lancar serta adanya kesanggupan dalam menghadapi pekerjaan yang menjadi tanggung jawabnya sebagai seorang pegawai.

Mulyasa (2014) mengatakan bahwa kepala sekolah adalah salah satu komponen pendidikan yang paling berperan dalam meningkatkan kualitas pendidikan. Kepala sekolah adalah penanggung jawab atas penyelenggaraan pendidikan, administrasi sekolah, pembinaan tenaga pendidikan lainnya, pendayagunaan serta pemeliharaan sarana dan prasarana juga sebagai supervisor pada sekolah yang dipimpinnya. Jika dilihat dari syarat guru untuk menjadi kepala sekolah, kepala sekolah bisa dikatakan sebagai jenjang karier dari jabatan fungsional guru. Apabila seorang guru memiliki kompetensi sebagai kepala sekolah dan telah memenuhi persyaratan atau tes tertentu maka guru tersebut dapat memperoleh jabatan kepala sekolah (Putri dkk, 2020; Maryanti dkk, 2020; Khasanah dkk, 2019; Kartini dkk, 2020).

\section{METODE PENELITIAN}

Penelitian ini dilaksanakan di Madrasah Aliyah Negeri (MAN) 1 Banyuasin beralamat di jalan K.H Sulaiman kelurahan Kedondong Raye Kecamatan Banyuasin III kabupaten Banyuasin. Penelitian ini dilaksanakan selama 4 bulan terhitung dari bulan Mei tahun 2020 sampai Agustus tahun 2020.

MAN 1 Banyuasin merupakan sekolah berbasis agama satu-satunya berstatus negeri di kecamatan Banyuasin III, sekolah ini merupakan sekolah yang memiliki jumlah siswa terbanyak dari beberapa sekolah madrasah/sederajat yang ada di kecamatan Banyuasin III, dengan status akreditas sekolah "A", sekolah ini memiliki banyak prestasi akademik dan non akademik. Penentuan MAN 1 Banyuasin menjadi tempat dilksanakannya penelitian ini untuk mendeskripsikan bagaimana tingkat disiplin kerja guru yang bertugas di MAN 1 Banyuasin.

Penelitian ini merupakan penelitian deskriptif dengan pendekatan kualitatif. Peneliti menggunakan jenis penelitian kualitatif. Menurut Tohirin (2011) penelitian kualitatif merupakan penelitian yang berupaya membangun pandangan orang yang diteliti secara rinci serta dibentuk dengan kata-kata, gambaran holistik (menyeluruh dan mendalam) dan rumit. Menurut Afifuddin (2009) metode penelitian kualitatif adalah metode penelitian yang digunakan untuk meneliti kondisi objek yang alamiah.

Fokus penelitian ini dimaksudkan untuk membatasi studi kualitatif sekaligus membatasi penelitian guna memilih mana data yang relevan dan mana yang tidak relevan (Moleong, 2010). Pembatasan dalam penelitian kualitatif ini lebih didasarkan pada tingkat kepentingan dari masalah yang dihadapi dalam penelitian ini. Penelitian ini difokuskan pada peran kepala MAN 1 Banyuasin kecamatan Banyuasin III kabupaten Banyuasin, jadi objek utamanya adalah kepala MAN 1 Banyuasin Kecamatan Banyuasin III kabupaten Banyuasin dan siswa MAN 1 Banyuasin kecamatan Banyuasin III kabupaten Banyuasin berjumlah 4 orang.

Sumber data dalam penelitian adalah subjek dari mana data diperoleh. Adapun dalam penelitian iani, penulis mengelompokan sumber data menjadi dua bagian, yaitu data primer dan data sekunder.

Menurut Sugiyono (2017) analisis data adalah proses menyusun secara sistematis data yang diperoleh dari hasil wawancara, catatan lapangan, dan dokumentasi, dengan cara mengorganisasikan data ke dalam kategori, menjabarkan ke dalam unit-unit, melakukan 
sintesa, menyusun ke dalam pola, memilih mana yang penting dan yang akan dipelajari, dan membuat kesimpulan sehingga mudah difahami oleh diri sendiri maupun orang lain. Analisis data dalam penelitian kualitatif dilakukan sejak sebelum memasuki lapangan, selama di lapangan, dan setelah selesai di lapangan.

\section{HASIL DAN PEMBAHASAN \\ Peran Kepala Sekolah dalam Menerapkan Disiplin Kerja Guru MAN 1 Banyuasin Kecamatan Banyuasin Kabupaten Banyuasin}

Disiplin kerja guru MAN 1 Banyuasin kabupaten Banyuasin sudah baik, berkaitan dengan tingkat kehadiran informasi dari kepala MAN 1 Banyuasin kabupaten Banyuasin bahwa tingkat kehadiran guru di MAN 1 Banyuasin kabupaten Banyuasin cukup baik, guru dan tenaga kependidikan di MAN 1 Banyuasin kabupaten Banyuasin cukup memiliki kesadaran yang baik untuk hadir di sekolah untuk melaksanakan tugas mereka. Guru selalu datang ke sekolah tepat waktu, informasi yang di dapatkan peneliti dari kepala MAN 1 Banyuasin kabupaten Banyuasin bahwa guru MAN 1 Banyuasin kabupaten Banyuasin selalu hadir tepat waktu di sekolah untuk melaksanakan tugas, karena di MAN 1 Banyuasin kabupaten Banyuasin diterapkan sistem pengabsenan guru dan tenaga kependidikan dengan menggunakan pager print, artinya jika guru MAN 1 Banyuasin kabupaten Banyuasin terlambat hadir di sekolah untuk melaksanakan tugas, jelas mereka dianggap tidak hadir di MAN 1 Banyuasin kabupaten Banyuasin untuk melaksanakan tugas.

Banyak sekali hambatan yang di alami kepala MAN 1 Banyuasin kabupaten Banyuasin dalam menerapkan disiplin bagi guru MAN 1 Banyuasin kabupaten Banyuasin, salah satunya adalah sikap dan kepribadian guru MAN 1 Banyuasin kabupaten Banyuasin yang berbeda-beda, semangat kerja kerja guru MAN 1 Banyuasin kabupaten Banyuasin yang tidak sama, kendala lainnya adalah keterbatasan dana untuk menambah kesejahteraan guru di MAN 1 Banyuasin kabupaten Banyuasin, lingkungan kerja MAN 1 Banyuasin kabupaten Banyuasin yang masih kurang mendukung untuk meneggakan disiplin kerja bagi guru MAN 1 Banyuasin kabupaten Banyuasin.

Cara kepala MAN 1 Banyuasin kabupaten Banyuasin mengatasi masalah disiplin kerja guru yang kurang efektif di sekolah adalah dengan memberikan sangsi kepada guru yang melanggar disiplin kerja, memberikan penghargaan sebagai bentuk apresiasi atas prestasi kerja yang dicapai guru MAN 1 Banyuasin kabupaten Banyuasin, menciptakan lingkungan sekolah MAN 1 Banyuasin kabupaten Banyuasin yang aman dan nyaman, memenuhi hak guru MAN 1 Banyuasin kabupaten Banyuasin secara adil, memperlakukan guru MAN 1 Banyuasin kabupaten Banyuasin secara adil dan bijaksana sebagai rekan kerja. Mengenai peraturan yang diterapkan kepala MAN 1 Banyuasin kabupaten Banyuasin tentang kelonggaran dalam menerapkan disiplin kerja kepada guru, hasil wawancara peneliti dengan kepala MAN 1 Banyuasin kabupaten Banyuasin bahwa mengenai peraturan dalam menerapkan disiplin kerja di MAN 1 Banyuasin kabupaten Banyuasin sudah dibuat oleh kepala sekolah yang terdahulu dan telah disepakati untuk tetap dilaksanakan sampai dengan sekarang ini. Salah satu kelonggaran peraturan yang diterapkan di MAN 1 Banyuasin kabupaten Banyuasin adalah pemberian dispensasi bagi guru MAN 1 Banyuasin kabupaten Banyuasin yang sakit, namun kelonggran itu bukan berarti guru MAN 1 Banyuasin kabupaten Banyuasin yang sakit tersebut dibebaskan dari tugasnya, namun diberi kesempatan untuk mencari guru pengganti, agar bisa istirahat sampai sembuh dari sakitnya, kelonggaran lain adalah pemberian ini selama 3 hari bagi guru MAN 1 Banyuasin kabupaten Banyuasin yang punya urusan keluarga, tidak bisa diwakilkannya dengan orang lain.

Sedangkan solusi yang dilakukan kepala MAN 1 Banyuasin kabupaten Banyuasin mengatasi ketimpangan pelanggaran peraturan di MAN 1 Banyuasin kabupaten Banyuasin adalah dengan memberikan pembinaan, menjatuhkan sangsi dan melaporkannya ke pihak yang lebih berwenang, agar pelanggaran peraturan tersebut tidak terulang lagi.

Menegakkan suatu kedisiplinan penting bagi sekolah, sebab kedisiplinan berisikan peraturan-peraturan yang harus ditaati guru. Dengan kedisiplinan diharapkan dapat 
membuat pekerjaan seefisien mungkin. Disiplin kerja dapat dilihat sebagai sesuatu yang besar manfaatnya, baik bagi kepentingan organisasi maupun bagi para guru. Bagi organisasi adanya disiplin kerja akan menjamin terpeliharanya tata tertib dan kelancaran pelaksanaan tugas, sehingga diperoleh hasil yang optimal. Sedangkan bagi karyawan akan diperoleh suasana kerja yang menyenangkan sehingga akan menambah semangat kerja dalam melaksanakan pekerjaannya (Irmayani dkk, 2018; Tobari dkk, 2018).

Disiplin kerja perusahaan atau instansi dapat dikatakan baik menurut Soejono (2000) antara lain 1) Ketepatan waktu, tepat diartikan bahwa tidak ada selisih sedikitpun, tidak kurang dan tidak lebih, persis. Sedangkan waktu adalah serangkaian saat yang telah lewat, sekarang, dan yang akan datang berdasarkan pengertian tersebut dapat ditarik kesimpulan bahwa ketepatan waktu adalah hal keadaan tepat tidak ada selisih sedikitpun bila waktu yang ditentukan tiba; 2) Ketaatan pada peraturan, peraturan maupun tata tertib yang tertulis dan tidak tertulis dibuat agar tujuan suatu organisasi dapat dicapai dengan baik, untuk itu dibutuhkan sikap setia dari karyawan terhadap komitmen yang telah ditetapkan tersebut; dan 3) Kemampuan memelihara peralatan kantor : peralatan adalah salah satu penunjang kegiatan, agar kegiatan tersebut berjalan dengan lancar. Dengan penggunaan dan pemeliharaan peralatan yang sebaik-baiknya dapat mengurangi resiko atau kerusakan peralatan yang lebih berat. Merawat dan memelihara merupakan salah satu wujud tanggung jawab dari karyawan

\section{Disiplin Kerja Guru MAN 1 Banyuasin Kecamatan Banyuasin Kabupaten Banyuasin}

Berkaitan dengan disiplin kerja guru MAN 1 Banyuasin kecamatan Banyuasin III kabupaten Banyuasin berdasarkan hasil penelitian temuan yang peneliti dapatkan bahwa disiplin kerja guru MAN 1 Banyuasin kecamatan Banyuasin III kabupaten Banyuasin sudah baik. Guru sudah menyadari untuk mematuhi dan menaati segala yang berlaku di sekolah. Disiplin guru MAN 1 Banyuasin kecamatan Banyuasin III kabupaten Banyuasin yang baik akan mempercepat pencapaian tujuan sekolah, sedangkan disiplin yang merosot akan menjadi penghalang dan memperlambat pencapaian tujuan sekolah. Guru yang memiliki disiplin kerja yang baik, mereka akan bertanggungjawab terhadap tugas yang di embannya, oleh karena itu disiplin kerja merupakan cermin kualitas dari kinerja seorang guru. Semakin baik disiplin kerjanya, maka akan semakin baik pula output dari kinerjanya (Fitria, 2018; Fitria dkk, 2018; Khasanah dkk, 2019; Kartini dkk, 2020).

Menurut Hasibuan (2004), faktor disiplin sangat berpengaruh terhadap kinerja karyawan. Disiplin biasanya berbanding lurus terhadap produktivitas karyawan dalam suatu perusahaan, bila tingkat disiplin karyawan suatu perusahaan baik, maka tingkat produktivitas perusahaan itu juga akan baik. Penegakkan disiplin yang terlalu tinggi bisa memicu stres kerja bagi guru atau bisa juga memicu motivasi guru karena beberapa guru cenderung malas bekerja bila tidak ada penegakkan disiplin yang tegas (Renata dkk, 2018; Andriani dkk, 2018).

Fenomena ini sering terjadi dan secara langsung maupun tidak langsung akan mempengaruhi perilaku guru. Menurut Hasibuan (2004), kedisplinan merupakan fungsi Manajemen Sumber Daya Manusia (MSDM) yang terpenting dan kunci terwujudnya tujuan karena tanpa disiplin yang baik sulit terwujud tujuan yang maksimal. Guru MAN 1 Banyuasin Kecamatan Banyuasin III kabupaten Banyuasin memiliki tingkat kedisplinan yang tinggi, dibuktikan dengan tingkat kehadiran guru yang tinggi dan ketepatan waktu ketika masuk kerja.

Semakin baiknya disiplin kerja guru di Guru MAN 1 Banyuasin Kecamatan Banyuasin III kabupaten Banyuasin dipicu oleh pelaksanaan pengcekan kehadiran melalui aplikasi pager print yang berlaku di Guru MAN 1 Banyuasin Kecamatan Banyuasin III kabupaten Banyuasin.

Berkaitan dengan kedisiplinan guru MAN 1 Banyuasin Kecamatan Banyuasin III kabupaten Banyuasin dalam berpakaian, hasil penelitian ini menunjukkan juga bahwa guru MAN 1 Banyuasin Kecamatan Banyuasin III kabupaten Banyuasin juga menunjukkan bahwa guru MAN 1 Banyuasin Kecamatan Banyuasin III kabupaten Banyuasin sudah cukup disiplin 
dalam mengenakkan pakaian dinas sesuai dengan peraturan yang berlaku di MAN 1 Banyuasin Kecamatan Banyuasin III kabupaten Banyuasin. Kepala sekolah tidak segan untuk memanggil guru yang berpakaian tidak sesuai dengan peraturan yang telah ditetapkan. Sikap tegas yang ditunjukkan kepala MAN 1 Banyuasin Kecamatan Banyuasin III kabupaten Banyuasin juga menjadi faktor pendorong disiplinnya guru dalam berpakaian dinas.

\section{Faktor yang menghambat kepala sekolah dalam menerapkan disiplin kerja guru yang bertugas di MAN 1 Banyuasin kecamatan Banyuasin III kabupaten Banyuasin}

Ada beberapa faktor yang menghambat penegakan disiplin kerja guru oleh kepala MAN 1 Banyuasin kecamatan Banyuasin III kabupaten Banyuasin. Pertama adalah keadaan fisik atau biologis guru yang kurang sehat. Berdasarkan hasil wawancara peneliti dengan kepala MAN 1 Banyuasin kecamatan Banyuasin III kabupaten Banyuasin bahwa alasan sakit atau tidak sehat merupakan faktor dominan guru tidak dapat melaksanakan tugas dengan baik di MAN 1 Banyuasin kecamatan Banyuasin III kabupaten Banyuasin. Kepala madrasah mengatakan bahwa sebagian besar bahwa alasan guru tidak bisa melaksanakan tugas karena alasan sakit masih menjadi faktor dominan. Oleh karena itu untuk membuktikan bahwa guru tersebut berhalangan hadir di sekolah karena alasan ankit, kepala MAN 1 Banyuasin kecamatan Banyuasin III kabupaten Banyuasin memberikan dispensasi kepada guru yang bersangkutan, dan guru diminta untuk menunjukkan surat kterangan sakit kepada kepala sekolah.

Faktor kedua adalah kondisi tempat tinggal guru yang jauh dari lokasi sekolah. Kepala sekolah menyatakan bahwa sebagian besar guru yang mengajar di MAN 1 Banyuasin kecamatan Banyuasin III kabupaten Banyuasin berasal dari luar wilayah kota palembang kondisi jarak tempuh membuat guru datang terlambat ke sekolah untuk melaksanakan tugas secara maksimal, karena jarak dari rumah ke sekolah terlalu jauh, pada kegiatan pembelajaran jam pertama berdasarkan hasil observasi peneliti ada beberapa kelas yang tidak ada guru di kelas melaksanakan pembelajaran karen guru belum bisa hadir di sekolah. Rendahnya kesadaran dari guru untuk memaksimalkan kegiatan pembelajaran di kelas, pada dua jam terakhir, biasanya situasi belajar siswa di kelas menjadi kurang efektif, selain di sebabkan faktor kelelahan, faktor lain yang mempengaruhinya adalah guru kurang memiliki kemampuan untuk membangkitkan semangat siswa untuk belajar.

Faktor lain yang menjadi kendala kepala MAN 1 Banyuasin kecamatan Banyuasin III kabupaten Banyuasin dalam menerapkan disiplin kerja bagi guru adalah faktor geografis, berdasarkan hasil observasi peneliti MAN 1 Banyuasin kecamatan Banyuasin III kabupaten Banyuasin memiliki letak yang kurang strategis, karena kondisi sekolah ini bukan berada di pinggir jalan lintas yang banyak dilalui oleh transportasi umum. Kondisi ini juga tidak hanya membuat guru, tenaga kependidikan saja yang terlambat datang ke sekolah, namun juga siswa MAN 1 Banyuasin kecamatan Banyuasin III kabupaten Banyuasin banyak yang sering terlambat datang ke sekolah. Pernyataan kepala sekolah juga di dukung temuan peneliti di MAN 1 Banyuasin kecamatan Banyuasin III kabupaten Banyuasin yang menjadi objek penelitian, peneliti mengamati meskipun jam aktivitas pembelajaran sudah berjalan namun masih ada guru, siswa yang baru datang ke sekolah.

\section{SIMPULAN}

Peran kepala MAN 1 Banyuasin Kecamatan Banyuasin III kabupaten Banyuasin dalam menerapkan disiplin kerja bagi guru dengan memberlakukan jam kehadiran guru pukul 7.15 WIB dan pulang pukul 2.30 WIB sudah terealisasi dengan baik, selalu melakukan tindak lanjut kepada guru yang sering berhalangan hadir di sekolah. Penegakan disiplin melalui hukum juga diterapkan, bagi guru yang melanggarnya seperti pelanggaran pada pemakaian pakaian seragam dinas sesuai dengan aturan yang telah disepakati bersama. Sikap tegas kepala MAN 1 Banyuasin Kecamatan Banyuasin III kabupaten Banyuasin menjadi faktor pendorong disiplinnya guru dalam berpakaian dinas. Disiplin kerja guru sudah 
cukup baik, guru sudah mematuhi peraturan jam kehadiran, meninggalkan tugas kepada guru piket ketika berhalangan hadir di sekolah karena ada urusan tertentu. Guru telah mematuhi peraturan yang berlaku di sekolah dalam menggenakan pakaian seragam Faktor yang menghambat kepala sekolah dalam menerapkan disiplin kerja guru antara lain keadaan fisik atau biologis guru yang kurang sehat. Faktor kedua adalah kondisi tempat tinggal guru yang jauh dari lokasi sekolah.

\section{UCAPAN TERIMA KASIH}

Ucapan terima kasih diberikan kepada Kementerian Agama Banyuasin, Rektor Universitas PGRI Palembang, Direktur Pascasarjana Universitas PGRI Palembang dan Ketua Program Studi Magister Manajemen Pendidikan Universitas PGRI Palembang yang telah membantu dalam penyelesaian jurnal ini yang merupakan produk dari tesis. Kemudian terima kasih juga kepada teman-teman mahasiswa Pascasarjana Universitas PGRI Palembang dan semua pihak yang telah membantu penulisan dan penerbitan jurnal ini.

\section{DAFTAR PUSTAKA}

Andriani, S., Kesumawati, N., \& Kristiawan, M. (2018). The Influence of the Transformational Leadership and Work Motivation on Teachers Performance. International Journal of Scientific \& Technology Research, 7(7).

Anwar, P. M. (2011). Manajemen Sumber Daya Manusia. Bandung: Remaja Rosdakarya.

Apriana, D., Kristiawan, M., \& Wardiah, D. (2019). Headmaster's Competency In Preparing Vocational School Students For Entrepreneurship. International Journal of Scientific \& Technology Research, 8(8).

Arikunto, S. (2010). Prosedur Penelitian : Suatu Pendekatan Praktik, Edisi Revisi VI, Jakarta : PT Rineka Cipta.

Daryanto, M. (2009). Administrasi Pendidikan. Jakarta: Raja Grafindo Persada

Fitria, H. (2018). The Influence Of Organizational Culture And Trust Through The Teacher Performance In The Private Secondary School In Palembang. International Journal of Scientific \& Technology Research, 7(7).

Fitria, H., Mukhtar, M., \& Akbar, M. (2017). The Effect of Organizational Structure And Leadership Style on Teacher Performance In Private Secondary School. IJHCM (International Journal of Human Capital Management), 1(02), 101-112.

Hani, H. (2001). Manajemen Personalia dan Sumber Daya Manusia. Yogyakarta. BPFE

Irmayani, H., Wardiah, D., \& Kristiawan, M. (2018). The Strategy of SD Pusri In Improving Educational Quality. International Journal of Scientific \& Technology Research, 7(7).

Kartini, D., Kristiawan, M., \& Fitria, H. (2020). The Influence of Principal's Leadership, Academic Supervision, and Professional Competence toward Teachers' Performance. International Journal of Progressive Sciences and Technologies (IJPSAT), 20(1), 156-164.

Khasanah, U., Kristiawan, M., \& Tobari. (2019). The Implementation of Principals' Academic Supervision In Improving Teachers' Professionalism in the State Primary Schools. International Journal of Scientific \& Technology Research, 8(8).

Maryanti, N., Rohana, R., \& Kristiawan, M. (2020). The Principal's Strategy In Preparing Students Ready To Face the Industrial Revolution 4.0. International Journal of Educational Review, 2(1), 54-69.

Melayu. S. P H. (2012.). Manajemen Sumber Daya Manusia. Edisi Revisi, Cetakan ke 9. Jakarta: Bumi Aksara

Moekijat. (2002). Manajemen Tenaga Kerja dan Hubungan Kerja. Bandung; Pioner Jaya

Muhammad, R. (2007). Pengantar IImu Sosial. Jakarta: PT Rasindo

Muhamad, T. (2011). Metode Penelitian Kualitatif dalam Bimbingan dan Konseling. Jakarta: Raja Grafindo

Mulyasa, E. (2013). Manajemen Kepemimpinan Kepala Sekolah. Edisi Ketiga. Cetakan ketiga. Jakarta: Bumi Aksara

Mulyasa. E. (2003). Menjadi Kepala Sekolah Profesional. Bandung: Remaja Rosdakarya 
Nanang, F. (2013). Konsep Manajemen Berbasis Sekolah dan Dewan Sekolah. Bandung: CV Pustaka Bani Quraisy

Norman. (2012). Metode Penelitian. Yogyakarta: Andi Ofset

Nur, A. (2016). Manajemen Pendidik \& Tenaga Kependidikan. Yogyakarta: Goysen Publising

Permendikbud No 6 Tahun 2018 Tentang Penugasan Karyawan Sebagai Kepala Sekolah

Putri, M. N., Kristiawan, M., \& Rohana, R. (2020). Mapping Principal's Competency of Secondary School. International Journal of Educational Review, 2(2), 151-159.

Renata, R., Wardiah, D., \& Kristiawan, M. (2018). The Influence of Headmaster's Supervision and Achievement Motivation on Effective Teachers. International Journal of Scientific \& Technology Research, 7(4).

Rivai. V., \& Sagala, S. (2013). Manajemen Sumber Daya Manusia. Jakarta: PT Prenhallindo

Rivai, V. (2004). Performance Appraisal: Sistem yang Tepat Untuk Menilai Kinerja Pegawai dan Meningkatkan Daya Saing Perusahaan. Jakarta: Raja Grafindo Persada

Sagala, S. (2005). Konsep Pembelajaran Untuk Membantu Memecahkan Problematika Belajar dan Mengajar. Bandung: Alfabeta

Sastrohadiworyo. (2005). Pengantar Ilmu Manajemen. Jakarta: Rineka Cipta

Sedamaryanti. (2007). Sumber Daya Manusia dan Produktivitas Kerja. Bandung: Mandar Maju

Soejono. (2000). Manajemen Sumber Daya Manusia, Bandung:Alfabeta

Sondang. P. S. (2001). Manajemen Sumber Daya Manusia. Edisi Pertama Jakarta: Bumi Aksara

Suhertin. (2006). Kompetensi Keperawatan Suatu Tinjauan Teori. Yogyakarta: Pustaka Pelajar

Sugiyono. (2017). Metode Penelitian Kuantitatif, Kualitati dan R\&D. Bandung: Alfabeta

Sutikno. (2003). Psikologi Belajar. Jakarta: Rineka Cipta

Sutrisno. (2013). Manajemen Personalia. Edisi Revisi. Bandung: Pustaka Setia

Supandi. (2011). Strategi Menyiapkan Kesuksesan Anak Anda. Jakarta: PT Gramedia Pustaka

Stephen, R. (2005). Perilaku Organisasi. Edisi Kedua Belas. Jakarta: Salemba Empat

Tobari., Kristiawan, M., \& Asvio, N. (2018). The Strategy of Headmaster on Upgrading Educational Quality In Asean Economic Community (AEC) Era. International Journal of Scientific \& Technology Research, 7(4).

Tu'u, T. (2004). Peran Disiplin Pada Perilaku dan Prestasi Siswa. Jakarta: PT. Grasindo

Umar, U. (2007). Teori Perkembangan Belajar.jakarta: Pustaka Pelajar.

Undang-Undang RI Nomor 20 Tahun 2003 Tentang Sisitem Pendidikan Nasional

Utama, H. B., Al Kadri, H., Kristiawan, M., \& Lian, B. (2020). Dampak Pelaksanaan Full Day School Terhadap Disiplin Kerja Guru. JMKSP (Jurnal Manajemen, Kepemimpinan, dan Supervisi Pendidikan), 5(1), 44-50.

Wandasari, Y., Kristiawan, M., \& Arafat, Y. (2019). Policy Evaluation of School's Literacy Movement on Improving Discipline of State High School Students. International Journal of Scientific \& Technology Research, 8(4). 